\title{
IAMJ
}

INTERNATIONAL

AYURVEDIC

MEDICAL JOURNAL

\section{AN APPROACH TOWARDS THE DIAGNOSIS AND MANAGEMENT OF COVID 19 AS PER AYURVEDA}

\author{
Manjusha Satish Desai ${ }^{1}$, Varsha A. Samarai ${ }^{2}$, Amrapali V. Done ${ }^{3}$ \\ ${ }^{1}$ Assistant Professor, Rognidan Department, Dr. J. J. Magdum Ayurved Medical College, Jaysingpur, Kolhapur, \\ Maharashtra, India \\ ${ }^{2}$ Assistant Professor, Samhita Siddhant Department, Dr. J. J. Magdum Ayurved Medical College Jaysingpur, \\ Kolhapur, Maharashtra, India \\ ${ }^{3}$ Assistant Professor, Rasashastra and B.K. Department, Dr. J. J. Magdum Ayurved Medical College Jaysingpur \\ Kolhapur, Maharashtra, India
}

Corresponding Author: drmanjushap7@gmail.com

\section{https://doi.org/10.46607/iamj1409072021}

(Published Online: July 2021)

Open Access

(C) International Ayurvedic Medical Journal, India 2021

Article Received:12/06//2021 - Peer Reviewed:15/06/2021 - Accepted for Publication:18/06/2021

\section{Check for updates}

\section{ABSTRACT}

The world community is facing an unprecedented pandemic of novel coronavirus disease (COVID-19) caused by Severe Acute Respiratory Syndrome Coronavirus 2 (SARS-CoV- 2). SARS CoV-2, a highly infectious causative agent of this disease is transmitted through droplets, contact routes and aerosols. Even the most developed nations are having trouble limiting its spread and the disease is still spreading at an alarming rate. For filling the gaps and lacunas in the healthcare system this is high time to integrate different healthcare systems available to meet the ever-emerging health challenges. Despite worldwide efforts to contain it, the pandemic is continuing to spread for want of a clinically proven prophylaxis and therapeutic strategy. Even though no system of medicine has any evidence-based treatment for COVID-19 yet, clinical interventions are required to be put in place. Ayurveda has documented the first reference of epidemics as Janapadodhwamsa ("Jana" means "people" whereas the word "Pada" means "place of habitation" of Jana, any disease or conditions like natural calamities or disasters affected a Janpad, it was called Janpandodhwansa) and has given a scientific insight into its causes, effect, and prevention along with management strategies. The clinical profile of COVID-19 matches with Vata-Kapha dominant 
Sannipataja Jwara (Fever caused by Tridoshas) for which detailed treatment guidelines and an array of pharmaceutical preparations are described in Ayurvedic literature which is being practised by qualified Ayurvedic physicians effectively for a long. This paper highlights the Ayurvedic perspective of the COVID-19 along with its aetiology, prevention, prophylaxis, and management strategies through Ayurveda.

\section{Keywords: COVID-19, SARS CoV-2, Ayurveda, Vata-Kaphaja Jwar,Janapadodhwamsa.}

\section{INTRODUCTION}

The whole world is currently facing a grave pandemic COVID-19, which has exposed the weaknesses and lacunas in the healthcare system across the globe. This serious illness which has clutched around 174.06 million people and has resulted in near 37.5 lakh deaths across 213 countries till now ${ }^{1}$ has revealed the need for critical analysis and revamped approach towards healthcare. COVID-19 was the name given by WHO to disease caused by severe acute respiratory syndrome coronavirus 2 (SARS CoV-2) on 11th February 2020, which was first reported in the wake of an outbreak of pneumonia of unknown origin from the city of Wuhan in China on 31 December 2019. The outbreak was declared a Public Health Emergency of International Concern on 30th January 2020 and as a pandemic on 11th March 2020. ${ }^{2}$ Even with so many advancements in conventional medicine and technology, the diseases like COVID19 always remain a challenge to health care machinery and cause devastating effects.

Conventional medicine has been of limited value in battling the COVID-19 crisis till date ${ }^{3}$ and off label medications found effective on earlier strains of coronavirus are being used for the treatment ${ }^{4}$. Variety of drugs like chloroquine, hydroxychloroquine, Lopinavir and ritonavir, Interferon beta-1a, Famotidine, Nafamostat and camostat, Ivermectin, Nitazoxanide,

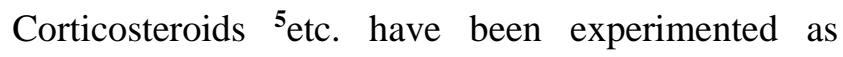
prophylactic as well as therapeutic agents but the majority of them were not found effective over the standard of care in trials and later few of them were discontinued by WHO on recommendations of Solidarity Trial's International Steering Committee. ${ }^{6}$ This crisis is a much-needed impetus to advance and explore Ayurveda principles and drugs for its utility to navigate through such unchartered territories of vari- ous health challenges. Many diseases of possible infectious aetiology like Jwara (fever), Visarpa (skin lesions), Kushtha (skin disorder), Masurika (chikenpox), Rajyakshama (tuberculosis), Krimi (worms), Aptanaka (tetanuslike condition) etc. had been documented in Ayurveda texts and the majority of them had been dealt with effectively and prognosticated as curable though may be challenging to treat. Presently in COVID19, conventional drugs being tried are ones that were found effective in previous pandemics but are not approved yet. When these medicines can be used without evidence then why not Ayurveda drugs which are being used effectively for since long. This article is an attempt to understand COVID-19 in the light of ancient Indian medical science i.e. Ayurveda with management strategies to be employed in this rapidly spreading infectious disease.

\section{DISCUSSION}

\section{According to W.H.O-Definition of COVID19}

COVID-19 is a disease caused by a new coronavirus called SARS-CoV-2. WHO first learned of this new virus on 31 December 2019, following a report of a cluster of cases of 'viral pneumonia in Wuhan, People's Republic of China.

Coronavirus (CoV):Coronaviruses are large, enveloped, positive-stranded RNA viruses having the largest genome among all RNA viruses ${ }^{7}$ ranging from 26 to 32 -kilo bases $(\mathrm{kb})$ in length. ${ }^{8}$ Due to spike glycoproteins on its surface, they appear like crown under the electron microscope, hence are termed as a coronavirus (coronam is the Latin term for crown). ${ }^{9}$ They belong to the Coronaviridae family in the order Nidovirales and are classified into Alphacoronavirus, Betacoronavirus, Gammacoronavirus and Deltacoronavirus genera ${ }^{7}$ Severe acute respiratory syndrome 
coronavirus( 2 )(SARS-CoV-2) belongs to the family of $\beta$-Coronaviruses. In research studies, the genome of this virus is found almost identical to that of bat coronavirus which points towards the bats being the possible natural hosts of the virus. ${ }^{10}$ Till now seven human Coronaviruses have been identified out of whom four coronaviruses namely HKU1, NL63, 229E and OC43 generally cause mild respiratory disease ${ }^{11}$ whereas members of Betacoronavirus genera SARS-CoV, MERS-CoV-2 are highly pathogenic ${ }^{\mathbf{1 2}}$

India and Covid-19: India confirmed its first case of novel coronavirus disease from the state of Kerala on 30th January $2020^{13 .}$ The government of India (GOI) took robust and courageous decisions to face the challenge and threat posed by the growing pandemic of Covid-19. Intending to contain the spread of coronavirus outbreak, GOI enforced the largest nationwide strict lockdown in four phases for 68 days. Relaxation in lockdown was initiated from 1st June 2020 in a phased manner and unlocking is in its third phase till the time of data compilation ${ }^{14}$ A second wave beginning in March 2021 was much larger than the first wave with a shortage of vaccines, hospital beds, oxygen cylinders, other medicines in a part of the country. ${ }^{15}$ By the April India led the world in new and active cases. On 30 April 2021, it became the first country to report over 4,00,000 new cases in 24 hours.$^{16,17}$ After all these strict measures number of infected individuals is still increasing at an alarming rate and till the time of writing this article, 29.3 million positive cases have been found with 10,89,248 active cases and 3,67,097deaths. All the departments and machinery of government along with the citizens are working hard to manage the threat posed by this disease. In this hard time, the greatest burden is on the health care system of the country and health care providers are also at the highest risk of acquiring the infection. Till now no definitive treatment of Covid19 is available ${ }^{\mathbf{1 8}}$.

Scientists are digging deep to unravel the mystery behind the course of the disease to find out the variation in response to infection from person to person. The answer for all these questions lies in the principle of Ayurveda "Purusham Purusham Veekshya"19that explains the individual uniqueness, their vulnerability towards diseases and personalized management strategies. So, it is high time to mainstream AYUSH in India to meet the needs of society through customized health care ${ }^{20,21}$

Vaccination Status in India: India began its vaccination programme on 16 January 2021, and by April was administering 3-4 million doses a day. ${ }^{22,23} 19$. India has authorized the British Oxford AstraZeneca Vaccine (Covishield), the Indian BBV152(Covaxin) vaccine and the Russian Sputnik V vaccine for emergency use. As of 25 May 2021, the country had administered over 200 million vaccine doses. $^{24}$

\section{Transmission and Prevention}

COVID-19 caused by SARS-Cov-2 is speculated to be transmitted through droplets, contact routes and aerosols generated (in specific hospital settings where procedures or support treatment that generate aerosols are performed and indoor settings with poor ventilation) from non-violent and violent expirations of SARS-CoV-2-infected people. ${ }^{25}$ Transmission of SARS-CoV-2 can occur through direct, indirect, or close contact with infected people through infected secretions such as saliva and respiratory secretions or their respiratory droplets, which are expelled when an infected person coughs, sneezes, talks or sings. Fomite (contaminated surfaces) transmission may occur indirectly through touching surfaces in the immediate environment or objects contaminated with a virus from an infected person, followed by touching the mouth, nose, or eyes.

The recommendations for preventing the spread in society are frequent hand hygiene, social distancing, respiratory etiquettes, environmental cleaning, and disinfection, avoiding outdoor and indoor crowded gatherings, wearing face masks to protect others and ensuring good ventilation in any closed setting. Effective control and limiting the spread of the virus can be achieved through identifying the suspected cases, increased testing capacity, strict quarantine (self or institutional), contact tracing and their isolation. ${ }^{26,27}$ 


\section{Historical evidence of infections and epidemics in Ayurveda}

The first documented evidence of infectious diseases in the modern medical literature is found in the writings of Hippocrates where he wrote about the means of disease spread by air, water, and places. ${ }^{28}$ Documentation of epidemics in Ayurveda have been done much before Hippocrates during the Vedic or postVedic period under the heading of Janpandodhwansa but has never been given the credit by the scientific community in the history of epidemics. Janapadas were the realms, republics, and kingdoms of the Vedic period on the Indian subcontinent. ${ }^{29}$ Term Janapada is composed of two words "Janas" and "Pada". "Jana" means "people" whereas the word "Pada" means "place of habitation" of Jana ${ }^{30}$

The earliest description of the term 'Janapada' is found in the Vedic literature Brahmanas, and post Vedic texts like Mahabharata and Ramayana. ${ }^{31}$ When any disease or conditions like natural calamities or disasters affected a Janpad, it was called Janpandodhwansa. Factors responsible for such an outbreak resulting in mass casualties are deranged Vayu (air), Jala (water), Desh (land) and Kala (seasons). These four factors are in common to habitants of an area which when vitiated are responsible for the outbreak of a disease. ${ }^{32}$ Sins of the present life and bad deeds of past life, Pragyaparadha (intellectual misconduct), Adharma (unrighteousness) have been ascribed as the root cause of such type of calamities. ${ }^{33}$ According to Thomas Love joy, a modern-day biologists who coined the term "biological diversity", the covid-19 pandemic is the consequence of human persistent and excessive intrusion in nature and the vast illegal wildlife trade, and in particular, the wildlife markets, the wet markets of south Asia and bushmeat markets of Africa which comes under the definition of unrighteous intellectual misconduct. ${ }^{34}$

\section{Ayurvedic approach to Covid-19}

Considering the mode of transmission (Oro-nasal route through droplets/hand contact), Covid-19 has Agantuja hetu (external cause i.e. SARS-CoV 2). Disease symptoms manifest abruptly without having the prodromal phase when the cause is Agantuj ${ }^{35}$ and the clinical presentation will depend upon the status of already deranged doshas at the site where they are maximally concentrated. After gaining entry in a host Agantuja hetu ultimately leads to derangement of Sharirika dosha (Vata, Pitta and Kapha) and gets converted to Nija (internal) type ${ }^{35}$ following the incubationperiod (variable, from 2-14 days in COVID19). ${ }^{36,37}$ Although the route of entry of SARS$\mathrm{CoV}-2$ is Oro-nasal and it mainly hits the respiratory system, but multiple organ system involvements are seen in different hosts. SARS CoV-2 after entering the body leads to derangement of Shareerika dosha and manifests mainly as Rasapradoshaja diseases (diseases caused due to vitiation of Ras dhatu) like Jwara (fever) and Arasagyata (loss of taste) ${ }^{\mathbf{3 8}}$ along with Pranavaha srotodushti symptoms (Pulmonary symptoms) like Shwasa (dyspnoea) and Kasa (cough). Annavaha Srotodushti (digestive system) symptoms like Aruchi (anorexia), Chardi (vomiting) and Purishavaha srotodushti (excretory system) symptoms like Atisara (diarrhoea) are also not uncommon. ${ }^{39}$ Other associated symptoms of COVID-19 are headache, body aches and arthralgia (Table-1) which are general symptoms associated with all the fevers. In the severe stage, the disease manifests as pneumonia, ARDS, shock, coagulation disorders with multi-organ failure ${ }^{50} \mathrm{All}$ these symptoms are described in Jwara under different types (Table 1) and COVID-19 can be categorized as Vata-Kapha dominant Sannipataja Jwara with variable involvement of Pitta. Hence, the line of treatment mentioned under Jwara chikitsa must be adopted for its management. In addition to this, principles of Shwasa and other diseases like Atisara (Diarrheal diseases), Chardi (Vomiting), Raktapitta (bleeding disorders and Coagulopathies) can be employed depending upon the presenting case. Jwara (fever) according to Ayurveda arises from Amashaya(stomach) and has been classified as a disease due to the vitiation of Rasavaha srotas. Aggravated Dosha (Vata, Pitta or Kapha) due to underlying aetiology, either alone or in a combination of two or three, gets mixed with the improperly formed Rasa (the first dhatu formed after digestion) which cause sluggish circulation and further blocks 
the microchannels of Rasa and Sweda (thermoregulatory apparatus). The Agni (digestive fire) gets displaced out of its original site (Paktisthana), spreading out through the body which is not able to dissipate heat due to blocked sweat channels, causing fever. ${ }^{41,42}$ Moreover, displacement of Agni from its seat im- pairs all the metabolic functions of the body ${ }^{\mathbf{4 3}}$ and leads to impaired immune response. ${ }^{44}$ Greater the derangement of agni greater will be the accumulated dosha and poor will be the prognosis ${ }^{45}$ as is seen in Covid-19.

Table 1: Clinical features of COVID19 as per Ayurveda

\begin{tabular}{|c|c|}
\hline Disease condition & Clinical Manifestation \\
\hline COVID-1946 & $\begin{array}{l}\text { Fever, Cough, Fatigue, Anorexia, Shortness of breath, Myalgia } \\
\text { Non-specific - Sore throat, nasal congestion, headache, diarrhoea, } \\
\text { nausea and vomiting. Loss of smell and Loss of taste }\end{array}$ \\
\hline Vata-KaphaJwara ${ }^{47}$ & Fever, Body aches, Cough, Coryza, Headache, Muscle and joint pain \\
\hline $\begin{array}{l}\text { VataKapha dominant, Recessive Pitta (Vata } \\
\text { Kapholbana HeenaPitta Sannipata) })^{48}\end{array}$ & Cold, Cough, Anorexia, Fatigue, Thirst, Burning, Body aches \\
\hline $\begin{array}{l}\text { TridoshajaJwara (VruddhaVata, Heena } \\
\text { Kapha, Madhya Pitta })^{49}\end{array}$ & Fever, Cough, Dyspnoea, Coryza, Pain in lower chest region or flanks \\
\hline Majjadhatugata Jwara ${ }^{50}$ & $\begin{array}{l}\text { Shwasa, Kasa, the affliction of vital organs, Fever, Fatigue, Syncopal } \\
\text { attacks }\end{array}$ \\
\hline
\end{tabular}

\section{Treatment approach}

Ayurveda primarily focuses on the preventive aspect of health through a set of guidelines mentioned under Dinacharya (daily regime), Ritucharya (seasonal regime), Dharniya and AdharniyaVega (suppression and non-suppression of urges), Sadvritta and Achara Rasayana (moral ethics) along with elaborate dietary recommendations. For therapeutic purposes, diagnostic, clinical and general, as well as disease-specific treatment guidelines, are also mentioned. As Covid19 is Sankramaka (communicable) disease having Agantuja cause resulting into Janapadodhwamsa (affecting a large geographical area), it also has preventive as well as curative angles to control its spread. Self-discipline, avoiding intellectual errors (following all recommended guidelines), to remember and follow the set of guidelines mentioned for prevention (dietary, daily and seasonal regimes, moral guidelines etc.) must be practised and they become even more important during epidemics.

During Covid-19, studies have shown significant impact temporary unemployment, online classes of children, lack of physical contact with other family members, friends and colleagues, loss of nears and dears due to covid-19 has resulted into fear, worry and stress. For minimizing the stress and anxiety truthfulness, compassion for living beings, charity,worship of God, observing moral conduct, protection of self (through various physical and spiritual methods), residing in an unaffected place (indicative of isolation), reading or listening toreligious scriptures, the constant association with the righteous must be practised.

\section{Prophylaxis}

Panchkarma (Five Ayurvedic Therapeutic cleansing methods) and Rasayana therapy (Immunomodulatory therapy) are mentioned as the cornerstone prophylactic modalities in Janpadodhwansa. ${ }^{51}$ Seasonal Panchakarma is recommended to remove the excess accumulated Doshas from the body for maintaining health. As it is difficult to perform Panchakarma during the outbreak of Covid-19, the utility of Rasayana becomes more important as they possess nutritive, restorative and immunomodulatory properties. $\mathrm{Ra}$ sayana acts as an antioxidant, anti-stress, antiinflammatory, anti-microbial and confer immunity against diseases. ${ }^{\mathbf{5 2}}$ Single-ingredient Rasayana drugs of potential benefit in Covid-19 are Withania somnifera, Tinospora cordifolia, Asparagus racemosus, Phyllanthus Emblica, Glycyrrhiza glabra, Piper 
longum and are recommended for its prophylaxis and as an add-on treatment. ${ }^{53}$ Chyavanaprasam, Brahm Rasayana, Pippali Rasayana, Amrita Bhallataka are also potential Rasayana in Covid $-19 .{ }^{54}$ Dhupana(fumigation) for disinfection of surroundings must be carried out with Ayurvedic drugs of antimicrobial properties ${ }^{55}$ which might limit the spread of the virus.

\section{Treatment:}

\section{Asymptomatic or Cases with Mild symptoms} Based On the treatment of Vata-Kapha Jwar-

Though Langhana (eat in minimum quantity) is the prime treatment modality for fevers in Ayurveda ${ }^{\mathbf{5 6}}$, in Covid-19 it must be used judiciously ${ }^{57}$ Deepana (increasing digestive fire), Pachana (increasing digestive capacity) with drugs dominating Tikta (bitter taste) and Katu (pungent) Rasa must be given to arrest or limit the severity of the disease. A light but nutritious diet must be given to the patient. Hot water or medicated water $\mathbf{5 8}$

\section{Moderate to Severe Cases}

Patients in this category must be treated on the line of treatment of Sannipataja Jwara with Vata-Kapha dominance, Shwasa and Kasa. Ayurvedic drugs of herbo-mineral origin with faster absorption, rapid action and better bioavailability ${ }^{59}$ must be prioritized in the treatment plan. Patients under these categories especially with co-morbidities require careful monitoring and an integrative treatment approach in intensive care settings must be adopted for better clinical outcomes. Ayurvedic drugs of significance in Covid19 which are routinely used by qualified Ayurveda practitioners are recommended according to the severity of the disease in Table 2. Ayurvedic drugs as add on therapy to recommended conventional treatment will result in a better outcome as was observed with TCM.

\section{Post-Covid care}

Fatigue and dyspnoea are persistent symptoms that are experienced after acute Covid-19. ${ }^{60}$ With a large number of recovered Covid-19 cases, ${ }^{61}$ a great pool of patients will be created who will likely end up in symptom complex as that of chronic post-SARS syndrome which includes fatigue, pain, weakness, depression and sleeps disturbance. ${ }^{\mathbf{6}}$ These patients can very well be managed using principles of Satvavjaya(psychological treatment), ${ }^{63,64}$ Unmada (a state of disturbed mental function), ${ }^{65}$ and Rasayana. ${ }^{\mathbf{6 6}}$ Ayurvedic therapeutic procedures like Abhyanga (oil message to whole body), Swedana (Steam bath), Avgahana (tub bath), Vasti (enema), Nasya (drug administration by nasal route), Shirodhara (dripping medicated oil or liquids on the forehead), Pranayama (breathing exercises) and Yoga will help these patients.

Table 2: Ayurvedic Medicines for management of Covid-19

The severity of the disease

Asymptomatic or Mild

Moderate

Severe

Post-COVID care

\section{Drug Recommendations}

Churna(powder) - Pippalichurna, Trikatu churna, Panchkola churna, Sitopaladi Churna, Talisadi churna Sudarshan churna

Kashaya (decoction) - Gojhivadi, Bharangayadi, Kantkaryadi

Herbomineral - Godanti mishran, Lakshmivilas Rasa, Tribhuvankirti Rasa

Vati (tablets) - Sudarshanghan vati, Samshamni vati, Lavangadi and Vyoshadi vati

Churna - Same as in mild cases

Kashaya (decoction) - Shatyadivarga kashaya, Kantkaryadi, Bharangayadi

Vati - Sanjivani vati, Sudarshanghan vati

Herbomineral - Godanti mishran, Tribhuvankirti Rasa, Mritunjaya Rasa, Kafketu Rasa, Shwaskuthar Rasa

Avaleha - Kantakari Avaleha, Agastya Haritaki Avaleha

Sanjivanivati, Hingukarpoorvati, Mritunjaya Rasa, Sameerpanag Rasa, Mala sindoor, Kasturibhairava rasa, Hema Garba Pottali, Trailokya Chintamani Ras, Suchikabharana Ras

Herbomineral- Vasantmalti rasa, Jayamangal rasa, Putpakvavishma Jwarantaklauha Avaleha-Chyavanprash Avaleha, Brahma Rasayana, Ashwagandhadi Leha, Sarpi Guda Churna-Sitopaladi Churna, Talisadi Churna

Ghrita(Ghee)-Indukant Ghrita, Dhanwantari ghrita, Amritprash Ghrita, Pippalyadi Ghrita 


\section{Dosing Considerations}

In Atyayika condition (emergency) Muhur -Muhur prayoga ${ }^{67}$ (frequent dosing) is suggested: Churnas are given in a dose of 3-4 gms in multiple doses up to 12 gms/day. While Sudarsana churna may be given as a Phanta Kalpana. Kasayam dosage depends upon the method of preparation. Aristas are given up to 50 $\mathrm{mL} /$ day. Except for Kanakasava which is given at 5$10 \mathrm{~mL}$ per dose twice daily. Dose of Rasasindoora with navasadara is $60-180 \mathrm{mg} /$ day while Rasasindoora without Navasadara 125$500 \mathrm{mg} / \mathrm{day}$ and Mallasindoora - 60-120 mg/day. Hema Garba Pottali (with Tamra) 60-125 mg 6th hourly, sub-lingually. Trailokya Chintamani Ras -60 -250 mg/day, sub-lingually; Suchikabharana Ras - 2$4 \mathrm{mg}$ over scalp incision along with $2-4 \mathrm{mg}$ orally with butter.

\section{AYUSH initiatives during Covid-19 Pandemic}

During the address to the nation, the Prime Minister of India urged the citizens to follow seven steps to fight corona $^{68}$ which included following AYUSH ministry guidelines for boosting immunity. AYUSH ministry issued an advisory to meet challenges arising out of the spread of coronavirus (Covid-19) in India ${ }^{69}$ along with Ayurveda's immunity-boosting measures for self-care duringCOVID-19 crisis $^{70}$ These guidelines consist of general measures such as drinking warm water, use of spices in cooking, the practice of Yoga, Pranayama and Asanas for at least 30 minutes,

Ayurvedic immunity promoting measures such as the use of Rasayana (e.g. Chyavanprash), herbal decoction and turmeric milk daily once or twice. Simple Ayurvedic procedures such as Pratimarsha Nasya (nasal application of oil or ghee) and Gandusha / Kawala (oil pulling therapy), steam inhalation and use of clove for throat irritation.

AYUSH guidelines also included the use of Samshamni vati for preventive and prophylactic care, AYUSH-64, Agastya Haritaki and Anu tail nasya for symptom management of Covid like illness and as add on therapy to conventional treatment along with dietary recommendations. AYUSH ministry also took up the research-related activities and issued guide- lines for the same based on recommendations of the interdisciplinary AYUSH R \& D task force. ${ }^{71}$ For scientifically evaluating the role of AYUSH interventions, population-based AYUSH studies for prophylaxis, AYUSH interventional studies for Covid-19, stand-alone AYUSH interventional studies, integrative clinical trials and AYUSH Sanjivani applicationbased study for impact assessment of acceptance and usage of AYUSH advisories for its role in the prevention of Covid 19 were planned as per guidelines and are being carried out. ${ }^{72}$

\section{CONCLUSION}

Infectious diseases like Covid-19, Zika virus disease, Ebola virus disease, H1N1 influenza are emerging at regular intervals that can wipe out the human generations and has unveiled the gaps in health care systems. It is high time to consider all the systems of healthcare available across the globe, study and test them scientifically to effectively control such diseases. Ayurveda, an ancient Indian medical wisdom having documented evidence of diseases of infectious aetiology has immense potential to contribute to society in such situations. Strong and visionary backup by the policymakers, unbiased outlook of the modern medical system and scientific community towards Ayurveda.

Mainstreaming AYUSH in healthcare policy with appropriate funding will pave the way forward. Ayurveda scholars also need to come out of the shell and develop scientific acumen by enhancing their skills through capacity building, upgrading their research skills and openness to modern science will benefit the system as well as the workforce. Scientific validation of Ayurvedic principles and drugs will make this science stand high in contemporary times and will help the ailing mankind but still a lot is required to be done.

\section{REFERENCES}

1. WHO coronavirus disease (Covid-19) dashboard. Geneva: World Health Organization; 2021. Available online: https://covid19.who.int/ (last cited: $[10 / 06 / 2021])$. 
2. Rolling updates on coronavirus disease (Covid-19). Events as they happen. Geneva: World Health Organization. Available online:https://www.who.int/emergencies/diseases/nov elcoronavirus-2019/events-as-they-happen 2020.

3. Rismanbaf A. Potential Treatments for Covid-19; a Narrative Literature Review. Arch Acad Emerg Med 2020; 8(1): e29.Published 2020 Mar 21.

4. Off-label use of medicines for Covid-19 Scientific Brief 31March 2020 | Covid-19: Clinical care. WHO referencenumber: WHO/2019-nCoV/Sci_Brief/Offlabel_use/2020.1(Accessed on 26 October 2020)

5. Leah Shaffer: 15 drugs being tested to treat Covid-19 and howthey would work. Nature medicine, news feature. Published2020 May 15. Available at: https://doi.org/10.1038/d41591-020-00019-9 (Accessed on 26 October 2020)

6. "Solidarity" clinical trial for Covid-19 treatments: World Health Organization. Available online: https://www.who.int/emergencies/diseases/novelcoronavirus-2019/globalresearch-on-novelcoronavirus-2019-ncov/solidarityclinical-trial-forcovid-19-treatments (Accessed on 26October 2020); 2020.

7. Li F. Structure, Function and Evolution of Coronavirus Spike Proteins. Annu Rev Virol 2016; 3(1): $237-$ 261. DOI:10.1146/annurev-virology-110615-042301

8. Malik YA. Properties of Coronavirus and SARS-CoV2. Malays J Pathol 2020; 42(1): 3-11.

9. Cascella M, Rajnik M, Cuomo A, et al. Features, Evaluationand Treatment Coronavirus (Covid-19) [Updated 2020 Jul 4]. In Stat Pearls [Internet]. Treasure Island (FL): Stat PearlsPublishing; 2020 Jan. Available from: https://www.ncbi.nlm.nih.gov/books/NBK554776/

10. Pascarella G, Strumia A, Piliego C, et al. Covid-19 diagnosis and management: a comprehensive review. J Intern Med2020; 288(2): 192-206. DOI: 10.1111/joim.13091

11. Singhal T. A Review of Coronavirus Disease-2019 (Covid- 19). Indian J Pediatr 2020; 87(4): 281-286. DOI: $10.1007 / \mathrm{s} 12098-020-03263-6$

12. Harapan H, Itoh N, Yufika A, et al. Coronavirus disease 2019(Covid-19): A literature review. J Infect Public Health. 2020;13(5): 667-673. DOI: 10.1016/j.jiph.2020.03.019

13. Responding to Covid-19 - Learnings from Kerala. Geneva: World Health Organization; 2020. Available from:

https://www.who.int/india/news/featurestories/detail/r esponding-to-covid-19---learnings-from Kerala).

14. Wikipedia contributors. (2020, August 11). Covid-19 lockdown in India. In Wikipedia. The Free Encyclopaedia. Retrieved 12:04, August 15; 2020. Fromhttps://en.wikipedia.org/w/index.php?title=COVI
D19_pandemic_lockdown_in_India\&oldid=97234818 2

15. Wikipedia contributors: Michael Safi(21 April 2021)." India's shocking surge in Covid cases follows baffling decline"The Guardian. Retrieved 29Aprill 2021

16. Wikipedia contributors: Coronavirus/ India becomes the first country in the world to report 4 lakh new cases on 30 April 2021, The Hindu-Special correspondent .30 April 2021.Retrieved 2 May 2021

17. Wikipedia contributors: BBC news.2 May 2021

18. Ali I, Alharbi OML. Covid-19: Disease, management, treatment, and social impact. Sci Total Environ 2020; 728: 138861. DOI: 10.1016/j.scitotenv.2020.138861

19. Charaka Samhita, Sutra sthana, Dirghamjivitiyamadhyaya 1/123. Available from: http://niimh.nic.in/ebooks/ecaraka

20. Shrivastava SR, Shrivastava PS, Ramasamy J. Mainstreaming of Ayurveda, Yoga, Naturopathy, Unani, Siddha and Homeopathy with the health care delivery system in India. J Tradit Complement Med 2015; 5(2): 116-118. Published 2015 Jan 7. DOI: 10.1016/j.jtcme.2014.11.002

21. Patwardhan B, Tillu G. Universal Health Coverage and AYUSH systems. J Ayurveda Integr Med 2018; 9(1): 1-2. DOI: 10.1016/j.jaim.2018.03.001

22. Wikipedia India fights corona COVID 19.My Gov. in.16 March 2020Retrieved $18^{\text {th }}$ Feb.2021

23. Wikipedia Daily COVID 19 Vaccine doses Administered- India Our world in Data.Retrieved 13th May 2021

24. Wikipedia 200 million vaccine doses administered in India. Hindustan Times 26 May 2021.

25. Jayaweera M, Perera H, Gunawardana B, Manatunge J. Transmission of Covid-19 virus by droplets and aerosols: Acritical review on the unresolved dichotomy [Published online ahead of print, 2020 Jun 13]. Environ Res 2020; 188:109819. DOI: 10.1016/j.envres.2020.109819

26. Transmission of SARS-CoV-2: implications for infection prevention precautions. Geneva: World Health Organization;2020 (Available online: https://www.who.int/newsroom/ commentaries/detail/transmission-of-sars-cov-2-implicationsfor-infection-prevention-precautions).

27. Infection prevention and control during health care when coronavirus disease (Covid-19) is suspected or confirmed: Interim guidance. Geneva: World Health Organization; 2020 (Available online: https://www.who.int/publications/i/item/WHO-2019nCoV-IPC-2020.4).

28. Philip S Brachman, Infectious diseases-past, present, and future, International Journal of Epidemiology 2003; 32(5):684-686 https://doi.org/10.1093/ije/dyg282

29. Wikipedia contributors. (2020, May 17). Janapada. In Wikipedia. The Free Encyclopaedia. Retrieved 18:31, 
August $\quad$ 14, 2020, from https://en.wikipedia.org/w/index.php?title=Janapada\& oldid=957205580; 2020.

30. Ramchandra, Gade Arun, Chousalkar, Ashok S. Politicalideas and constitutional experiments in Ancient Indianrepublics, Emergence of Republics in Ancient India, Chapter II, p. 53. Available from:http://hdl.handle.net/10603/139002.

31. Ramchandra, Gade Arun, Chousalkar, Ashok S. Politicalideas and constitutional experiments in Ancient Indianrepublics, Emergence of Republics in Ancient India, ChapterII, p. 56. Available from:http://hdl.handle.net/10603/139002.

32. Charaka Samhita, Vimana sthana, Janpadodhwansniyavimanam 3/6. Available from: http://niimh.nic.in/ebooks/ecaraka

33. Charaka Samhita, Vimana sthana, Janpadodhwansniyavimanam 3/20. Available from: http://niimh.nic.in/ebooks/ecaraka

34. 'We did it to ourselves: Scientist says intrusion into nature ledto the pandemic. The Guardian (Available at:https://www.theguardian.com/world/2020/apr/25/ou rselvesscientist-says-human-intrusion-naturepandemicaoe?CMP=share_btn_link).

35. Charaka Samhita, Nidanasthana, Jwara Nidanam 1/30.Available from: http://niimh.nic.in/ebooks/ecaraka

36. Backer JA, Klinkenberg D, Wallinga J. Incubation period of 2019 novel coronavirus (2019-nCoV) infections among travellers from Wuhan, China, 20-28 January 2020. Euro Surveill 2020; 25(5): 2000062. DOI: 10.2807/1560-7917.ES.2020.25.5.2000062

37. Centre for Disease Control and Prevention. Department of Health and Human Services. The US. Interim Clinical Guidance for Management of Patients with Confirmed Coronavirus Disease (Covid-19). Available from: https://www.cdc.gov/coronavirus/2019ncov/hcp/clinical-guidance-management patients.html

38. Charaka Samhita, Sutra sthana, Vividhashitpeetiya 28/9-11. Available from: http://niimh.nic.in/ebooks/ecaraka

39. Charaka Samhita, Vimana sthana, Srotovimaniya 5/8.Available from: http://niimh.nic.in/ebooks/ecaraka

40. Juan A. Siordia. Epidemiology and clinical features of Covid-19: A review of current literature, Journal of Clinical Virology, Volume 127, 2020, 104357, ISSN 1386-6532,https://doi.org/10.1016/j.jcv.2020.104357.

41. Charaka Samhita, Nidanasthana, Jwara Nidanam 1/20.Available from: http://niimh.nic.in/ebooks/ecaraka

42. Charaka Samhita, Chikitsasthana, Jwara chikitsitam 3/129-31. Available from: http://niimh.nic.in/ebooks/ecaraka

43. Charaka Samhita, Chikitsasthana, Jwara chikitsitam3/273,275. Available from: http://niimh.nic.in/ebooks/ecaraka
44. Charaka Samhita, Chikitsasthana, Grahani chikitsa15/3-4.Available from: http://niimh.nic.in/ebooks/ecaraka

45. Charaka Samhita, Chikitsasthana, Jwara chikitsitam 3/109.Available from: http://niimh.nic.in/ebooks/ecaraka

46. World Health Organization. Geneva. 2020. Clinical management of Covid-19. WHO Reference Number: WHO/2019-nCoV/clinical/2020.5. Available at:https://www.who.int/publications/i/item/clinicalman agement-of-covid-19

47. Charaka Samhita, Chikitsasthana, Jwara chikitsitam 3/86-87. Available from http://niimh.nic.in/ebooks/ecaraka

48. Charaka Samhita, Chikitsasthana, Jwara chikitsitam 3/92. Available from http://niimh.nic.in/ebooks/ecaraka

49. Charaka Samhita, Chikitsasthana, Jwara chikitsitam 3/101.Available from http://niimh.nic.in/ebooks/ecaraka

50. Charaka Samhita, Chikitsasthana, Jwara chikitsitam 3/81.Available from http://niimh.nic.in/ebooks/ecaraka

51. Charaka Samhita, Vimana sthana, Janpadodhwansniyavimanam 3/13. Available from http://niimh.nic.in/ebooks/ecaraka

52. Girish Tillu, Sarika Chaturvedi, Arvind Chopra and Bhushan Patwardhan. The Journal of Alternative and Complementary Medicine. May 2020.360-364. http://doi.org/10.1089/acm.2020.0129

53. Rege N.N., Thatte U.M. and Dahanukar S.A. Adaptogenic properties of six rasayana herbs used in Ayurvedic medicine. Phytother. Res 1999; 13: 275-291. DOI: $10.1002 /($ SICI) 1099 1573(199906)13:4<275::AID-PTR510>3.0.CO;2-S

54. Rastogi S, Pandey DN, Singh RH. Covid-19 pandemic: A pragmatic plan for Ayurveda intervention [Published online ahead of print, 2020 Apr 23]. J Ayurveda Integr Med 2020;S0975-9476(20)30019-X. DOI: 10.1016/j.jaim.2020.04.002

55. Bhatwalkar SB, Shukla P, Srivastava RK, Mondal R, Anupam R. Validation of environmental disinfection efficiency of traditional Ayurvedic fumigation practices. JAyurveda Integr Med 2019; 10(3): 203-206. DOI:10.1016/j.jaim.2019.05.002

56. Charaka Samhita, Chikitsasthana, Jwarachikitsitam 3/139.Available from http://niimh.nic.in/ebooks/ecaraka

57. Sidhinandan Mishra, Bhaishajya Ratnavali, Jwaradhikara,5/323, Varanasi: Chaukhambha Surbharti Prakashan; 2011. p.116.

58. Charaka Samhita, Chikitsasthana, Jwara chikitsitam 3/143-45. Available from http://niimh.nic.in/ebooks/ecaraka

59. Savrikar SS, Ravishankar B. Introduction to 'Rasa Shastra' the Iatrochemistry of Ayurveda. Afr J Tradit 
Complement Altern Med 2011; 8(5 Suppl): 66-82. DOI: 10.4314/ajtcam.v8i5S.1

60. Carfi A, Bernabei R, Landi F, for the Gemelli Against Covid-19 Post-Acute Care Study Group. Persistent Symptoms inPatients after Acute Covid-19. JAMA 2020; 324(6): 603- 605. DOI: 10.1001/jama.2020.12603

61. Worldometers.info [homepage on the Internet]. The United States. Worldo meter Covid-19 Data.

62. Moldofsky, H., Patcai, J. Chronic widespread Musculo skeletal pain, fatigue, depression and disordered sleep in chronic post-SARS syndrome; a case-controlled study. BMC Neurol 2011; 11, 37. https://doi.org/10.1186/1471-2377-11-37

63. Amin H, Sharma R. Nootropic efficacy of Satwavajaya Chikitsa and Ayurvedic drug therapy: A comparative clinical exposition. International Journal of Yoga 2015 Jul-Dec; 8(2):109-116. DOI: 10.4103/09736131.158473.

64. Rawal P, Vyas M, Baghel AS, Kamble S. Efficacy of Satwavajaya Chikitsa in the form of relaxation techniques and Guda Pippalimula Churna in the management of Anidra (insomnia) - An open labelled, randomized comparativeclinical trial. Ayu 2019; 40(2): 89-96. DOI:10.4103/ayu.AYU_91_17

65. Shreevathsa M, Ravishankar B, Dwivedi R. Antidepressantactivity of Mamsyadi Kwatha: An Ayurvedic compoundformulation. Ayu 2013; 34(1): 113-117. DOI: 10.4103/0974-8520.115448

66. Deole YS, Chavan SS, Ashok BK, Ravishankar B, ThakarAB, Chandola HM. Evaluation of antidepressant andanxiolytic activity of Rasayana Ghana Tablet (A compound Ayurvedic formulation) in albino mice. Ayu 2011; 32(3):375-379. DOI: 10.4103/09748520.93918

67. (1st ed.) K. Lochan (Ed.), Ashtanga Hridaya of Vagbhatta, vol.2, Chaukhambha Publications, New Delhi (2017)

68. www.timesofindia.indiatimes.com Covid-19: PM Narendra Modi asks citizens to follow these seven steps. The Times ofIndia, (Updated 2020, April 14, cited 2020 August 16). Available from: https://timesofindia.indiatimes.com/india/from-caringfor-elders-to-honouring-frontline-staff-pmnarendramodi-seeks-peoples-support-insevenareas/articleshow/75134524.cms

69. www.ayush.gov.in Ministry of AYUSH (March 2020).Advisory from Ministry of AYUSH for meeting the challenge arising out of the spread of coronavirus (Covid19) in India. Available from: https://www.ayush.gov.in/

70. www.ayush.gov.in Ministry of AYUSH (March 2020). Ayurveda immunity-boosting measures for selfcare during Covid 19 crisis. Available from: https://www.ayush.gov.in/
71. www.ayush.gov.in Ministry of AYUSH, Government of India. Interdisciplinary AYUSH Research and development task force - Guidelines for AYUSH clinical studies in Covid-19. (2nd April - 2nd May 2020) Available from: https://www.ayush.gov.in/

72. www.health.ncog.gov.in/ayush-coviddashbaord/homeMinistry of AYUSH. Tentative Proposed list of activities. Available at https://health.ncog.gov.in/ayushcoviddashbaord/assets /Classified/Research_studies.docx

\section{Source of Support: Nil Conflict of Interest: None Declared}

How to cite this URL: Manjusha Satish Desai et al: An Approach Towards The Diagnosis And Management Of Covid 19 As Per Ayurveda. International Ayurvedic Medical Journal \{online\} 2021 \{cited July 2021\} Available from: http://www.iamj.in/posts/images/upload/1409_1418.pdf 